\title{
Pasuwitan Sebagai Legalitas Perkawinan: Telaah Hukum Islam terhadap Perkawinan Suku Samin di Kabupaten Pati
}

\author{
Muhammad Taufiq* \& Anis Tyas Kuncoro** \\ *Universitas Islam Negeri Sunan (UIN) Sunan Kalijaga \\ Yogyakarta \\ **Universitas Islam Sultan Agung (UNISSULA), Semarang \\ Email: taufiqmuham27@gmail.com
}

\begin{abstract}
Marriage is a sacred relationship. A man and woman are declared to be legitimate husband and wife when they have done marriage ceremony and have fulfilled requirement and marriage, but society of Samin in Baturejo Village Sukolilo Sub-district Pati Regency has rules where a man and woman declared as legitimate as husband and wife if you have an intimate relationship called pasuwitan tradition. This research is descriptive research type of analysis by using descriptive method. In order to obtain more detailed data, the authors also use interviews. The results of this study revealed that pasuwitan is a process whereby a bride lives a house with a bride to undergo a matching process, matches marked by having sex. After that both are declared legitimate as husband and wife. Based on the analysis of Islamic law the existing tradition in the Samin society is not to be done because this tradition contradicts the syara 'argument. This tradition can be regarded as 'urf (local tradition) but 'unacceptable 'urf because it does not qualify as 'urf ('urf fasid) which justifies the haram. Meanwhile, if viewed from the terms and pillars of marriage, pasuwitan tradition is done without a

* Mahasiswa Program Magister Interdisciplinary Islamic Studies Universitas Islam Negeri (UIN) Sunan Kalijaga, Yogyakarta.

** Dosen Program Studi Ahwal Syakhshiyyah, Jurusan Syariah, Fakultas Agama Islam, Universitas Islam Sultan Agung (UNISSULA), Semarang.
\end{abstract}


clear qabul ijab. Whereas in the provisions of qabul ijab in the marriage it must be a married statement from the guardian and spoken clearly and use the words of marriage or tazwij. So the marriage in this pasuwitan tradition can be regarded as illegitimate marriage because it does not fulfill the contract in actual marriage.

Keywords: Legality of Marriage, Pasuwitan, 'Urf.

\section{Abstrak}

Perkawinan merupakan hubungan yang sakral. Seorang pria dan wanita dinyatakan sah menjadi pasangan suami isteri ketika sudah melaksanakan akad nikah serta telah memenuhi syarat dan rukun nikah, namun masyarakat Suku Samin yang ada di Desa Baturejo Kecamatan Sukolilo Kabupaten Pati mempunyai aturan dimana seorang pria dan wanita dinyatakan sebagai sah sebagai seorang suami isteri apabila telah melakukan hubungan intim yang disebut tradisi pasuwitan. Penelitian ini merupakan jenis penelitian deskriptif analisis dengan menggunakan metode deskriptif. Dalam rangka medapatkan data lebih detail, penulis juga menggunakan wawancara. Hasil penelitian ini mengungkapkan bahwa pasuwitan adalah proses dimana seorang pengantin laki-laki hidup satu rumah dengan pengantin perempuan untuk menjalani proses pencocokan, kecocokan ditandai dengan telah melakukan hubungan intim. Setelah itu baru keduanya dinyatakan sah sebagai suami isteri. Berdasarkan analisis hukum Islam tradisi yang ada di masyarakat Suku Samin ini tidak boleh untuk dilakukan karena tradisi ini bertentangan dengan dalil syara'. Tradisi ini bisa dikatakan sebagai 'urf tetapi 'urf yang tidak dapat diterima karena tidak memenuhi syarat sebagai 'urf ('urf fasid) yaitu menghalalkan yang haram. Sedangkan jika dilihat dari syarat dan rukun nikah, tradisi pasuwitan dilakukan tanpa ijab qabul yang jelas. Padahal dalam ketentuan ijab qabul dalam perkawinan itu harus ada pernyataan menikahkan dari wali serta diucapkan dengan jelas dan menggunakan kata-kata nikah atau tazwij. Sehingga perkawinan dalam tradisi pasuwitan ini bisa dikatakan sebagai nikah yang tidak sah karena tidak memenuhi akad dalam perkawinan yang sebenarnya.

Kata kunci: Legalitas Nikah, Pasuwitan, 'Urf.

Ulul Albab: Jurnal Studi dan Penelitian Hukum Islam 
Pasuwitan Sebagai Legalitas .... $\mid 55$

\section{Pendahuluan}

erkawinan merupakan masalah yang esensial bagi
kehidupan manusia, karena disamping perkawinan
sebagai sarana untuk membentuk keluarga, perkawinan juga merupakan kodrati manusia untuk memenuhi kebutuhan seksualnya, pada dasarnya perkawinan tidak hanya masalah hubungan manusia dengan manusia tetapi terkait juga hubungan sakralitas, yaitu hubungan manusia dengan Tuhannya. Sehingga setiap agama memiliki aturan tersendiri dalam hal perkawinan. ${ }^{1}$

Pada pasal 1 Undang-Undang Perkawinan Nomor 1 Tahun 1974 menjelaskan bahwa perkawinan dilakukan untuk membentuk keluarga (rumah tangga) yang bahagia dan kekal berdasarkan Ketuhanan Yang Maha Esa. ${ }^{2}$ Mengacu dari Undang-Undang Perkawinan tersebut maka muncul asas-asas prinsipil, salah satunya yaitu perkawinan menganut prinsip bahwa calon suami isteri harus telah masuk jiwa dan raganya untuk dapat melangsungkan perkawinan, agar dapat mewujudkan tujuan perkawinan secara baik tanpa berpikir perceraian dan mendapat keturunan yang baik dan sehat. ${ }^{3}$

Tanpa perkawinan, manusia tidak dapat melanjutkan sejarah hidupnya, karena keturunan dan perkembangan manusia disebabkan oleh adanya perkawinan. Jika perkawinan manusia tanpa didasarkan pada hukum Allah, sejarah dan peradaban manusia akan hancur oleh bentuk-bentuk perzinaan. ${ }^{4}$

Perkawinan bukan hanya mempersatukan dua pasang manusia laki-laki dan perempuan, melainkan mengikatkan tali

\footnotetext{
${ }^{1}$ Wasman dan Wardah Nuroniyyah, Hukum Perkawinan Islam Indonesia, (Yogyakarta: Mitra Utama, 2011), 30.

2 Undang-Undang Perkawinan No 1 Tahun 1974, (Bandung: Citra Umbara, 2012), 2.

${ }^{3}$ Ahmad Rofiq, Hukum Islam di Indonesia, (Jakarta: PT. Sinar Grafika, 2010), 107.

${ }^{4}$ Ibid., 16-17.
} 
56 | Muhammad Taufik \& Anis Tyas Kuncoro

perjanjian suci atas nama Allah bahwa kedua mempelajari berniat membangun rumah tangga yang sakinah, tentram, dan dipenuhi oleh rasa cinta dan kasih sayang. ${ }^{5}$

Dalam tradisi masyarakat Indonesia, perkawinan bisa dinilai sebagai sebuah ritual yang dilakukan secara khidmat dan sakral karena harus mematuhi sebuah aturan dan syarat-syarat tertentu dalam menjalankannya. Menurut Victor Turner ritual diartikan sebagai perilaku tertentu yang bersifat formal, dilakukan dalam waktu tertentu secara berkala, bukan sekedar sebagai rutinitas yang bersifat teknis, melainkan menunjuk pada tindakan yang didasari oleh keyakinan religius terhadap kekuasaan atau kekuatan-kekuatan mistis. ${ }^{6}$

Masyarakat Suku Samin adalah masyarakat yang identik dengan kehidupan pedesaan, pertanian sebagai sumber kehidupan utama, dan tiga hal mendasar yang membedakan dengan masyarakat non-Samin yakni dalam hal perkawinan, perawatan jenazah dan penyembelihan hewan karena pijakan hidupnya adalah agama Adam. ${ }^{7}$ Masyrakat Suku Samin menyebut perkawinan dengan istilah bebrayan, serta menyebut pasangannya dengan istilah rerukunan. Di dalam menjalankan perkawinan masyarakat Suku Samin tidak menjalankan aturan sebagaimana masyarakat pada umumnya, mereka enggan mematuhi aturan-aturan yang telah ditetapkan oleh pemerintah seperti Undang-Undang Perkawinan No 1 tahun 1974 dan Kompilasi Hukum Islam, padahal mereka merupakan warga penduduk Negara Indonesia yang mengaku sebagai seorang muslim.

${ }^{5}$ Beni Ahmad Saebani, Perkawinan Dalam Hukum Islam dan UndangUndang, (Bandung, Pustaka Setia, 2008), 15.

${ }^{6}$ Victor Witter Turner. The Ritual Process: Strukture and Anti-Strukture, (New York: Cornell University Press, 1966), 19.

${ }^{7}$ Agama Adam adalah agama lokal yang dianut oleh masyarakat Suku Samin.

Ulul Albab: Jurnal Studi dan Penelitian Hukum Islam 
Dalam perkawinan masyarakat Samin terdapat beberapa tahapan, yaitu:

1. Nyumuk yaitu kedatangan orang tua calon kemanten putra ke calon kemanten putri untuk menanyakan keberadaan calon menantu, apakah sudah mempunyai calon suami atau masih gadis (legan).

2. Ngendek yaitu pernyataan orang tua calon kemanten putra kepada bapak-ibu calon kemanten putri, menindak lanjuti proses nyumuk. Pada prosesi ini biasanya ibu dari pihak calon kemanten putra memberikan cincin emas sebagai tanda telah diwatesi.

3. Nyuwito yaitu hari dilangsungkannya perkawinan didasari niat kemanten putra untuk meneruskan keturunan (wiji sejati, titine anak adam). Rentan waktu Nyuwito tidak dibatasi, dan ditentukan oleh kedua kemanten jika sudah cocok. Kecocokan itu ditandai dengan keduanya telah melakukan hubungan intim.

4. Pasaksen yaitu forum ungkapan dari kemanten putra di hadapan orang tua kemanten putri, keluarga dan tamu undangan bila kemanten putra sudah merasa cinta dan berjanji setia terhadap pasangannya, ungkapan tersebut dilakukan setelah kemanten putra-putri melakukan hubungan intim. ${ }^{8}$

Dari tahapan perkawinan tersebut, proses pasuwitan atau nyuwito dianggap sebagai sahnya suatu perkawinan ditandai dengan kecocokan dari kedua calon pengantin dimana telah melakukan hubungan intim. Padahal hukum Islam sudah diatur, perkawinan sah bila telah memenuhi syarat dan rukun perkawinan, baru kemudian dapat melakukan hubungan intim.

Dalam tulisan ini, penulis bermaksud untuk membahas perkawinan masyarakat Suku Samin di Desa Baturejo

${ }^{8}$ Wawancara dengan Kepala Suku Samin pada tanggal 23 Desember 2016 pukul 09.00. 
$58 \mid$ Muhammad Taufik \& Anis Tyas Kuncoro

Kecamatan Sukolilo Kabupaten Pati dengan pendekatan sosiologis yang bersifat yuridis empiris, pendekatan tersebut digunakan untuk melihat aspek-aspek hukum dalam interaksi sosial di dalam masyarakat. Pengumpulan data juga dilakukan dengan wawancara, dokumentasi. Data yang telah terkumpul kemudian dianalisis dengan menggunakan metode deskriptif kualitatif.

\section{Sejarah Masyarakat Suku Samin di Kabupaten Pati}

Masyarakat Samin (Sedulur Sikep) adalah keturunan para pengikut Ki Samin Surosentiko yang mengajarkan Sedulur Sikep, dimana dia mengobarkan semangat perlawanan terhadap Belanda dalam bentuk lain di luar kekerasan. Sedulur Sikep hidup secara tersebar di pantai utara Jawa Tengah, seperti Kudus, Pati, Blora, Rembang, Bojonegoro bahkan sampai ke Ngawi. ${ }^{9}$

Pada tahun $1890 \mathrm{Ki}$ Samin Surosentiko mulai mengembangkan ajarannya di Desa Klopoduwur (Blora). Sejak tahun 1905 orang-orang desa yang menganut ajaran Samin mulai mengubah tata cara hidupnya dalam pergaulan seharihari di desanya. Mereka tidak mau lagi menyetor di lumbung desa, membayar pajak dan mengandangkan sapi dan kerbau di kandang umum bersama orang desa lainnya yang bukan orang Samin (Sedulur Sikep). Pada tahun 1907 Ki Samin Surosentiko dan beberapa pengikutnya ditangkap Pemerintah Kolonial Belanda, selanjutnya dibuang di luar pulau Jawa dan tahun 1914 $\mathrm{Ki}$ Samin Surosentiko meninggal di Padang. Ki Samin Surosentiko memiliki 3 (tiga) buah sawah 1 (satu) buah ladang kering dan 6 (enam) ekor sapi.

Penangkapan Ki Samin Surosentiko tidak memadamkan pergerakan Samin. Wongsoredjo pengikut Samin giat

${ }^{9}$ Anis Sholeh Ba'asyin, Samin Mistisme Petani di Tengah Pergolakan, (Semarang: Gigih Pustaka Mandiri, 2014), 139.

Ulul Albab: Jurnal Studi dan Penelitian Hukum Islam 
menyebarkan ajaran Samin di Distrik Jiwan, Madiun. Mulai tahun 1911 Surokidin, menantu Ki Samin Surosentiko dan Engkrak, murid Ki Samin Surosentiko menyebarkan ajaran Samin ke daerah Grobogan (Purwodadi). Karsiyah, pengikut Ki Samin Surosentiko, menyebarkan ajaran Samin ke daerah Kajen (Pati). Pada tahun 1916 orang Samin mencari daerah baru untuk mengembangkan ajarannya dan dikembangkan di Undaan (Kudus). Pada tahun 1917, Pak Engkrak mengadakan perlawanan dengan Pemerintah Kolonial Belanda dengan apa yang dinamakan "pratikel pasip", yaitu perlawanan dengan bersikap pasif yang sangat menjengkelkan Belanda dan akhirnya dapat digagalkan. Semua ajaran Samin diajarkan berdasar tradisi lisan, tetapi ditemukan "manuskrip" (naskah tulisan tangan) berjudul Serat Punjer Kawitan (ditulis dalam aksara jawa) yang telah berumur 70 tahun yang ditemukan di Tapelan, Bojonegoro.

Pandangan hidup masyarakat Sikep yang di hayati dan dilampahi (dijalani) secara patuh dan konsekuen, sehingga menjadi budaya yang tersendiri yang membedakan masyarakat Sikep dari lingkungan sosial yaitu masyarakat bukan Sikep. Contohnya, dihindarinya matapencaharian "berdagang" sebagai pilihan profesi untuk mendapatkan nafkah. Begitu pula tidak diterimanya sistem pendidikan formal persekolahan sebagai sarana sangat penting untuk generasi mudanya. ${ }^{10}$

Penamaan terhadap komunitas yang disebut sebagai masyarakat Samin sesungguhnya merupakan masyarakat penganut ajaran Saminisme yang dikembangkan oleh Ki Samin Surosentiko. Nama asli Ki Samin Surosentiko adalah Raden Kohar yang lahir pada tahun 1859 di Desa Ploso Kedhiren, Randublatung, Blora. Namanya kemudian diubah menjadi Samin, yaitu nama yang bernafas kerakyatan. Selanjutnya dia

${ }^{10}$ Stefanus Laksanto Utomo, Budaya Hukum Masyarakat Samin, Cet.1, (Bandung: PT. Alumni, 2013), 191-192. 
$60 \mid$ Muhammad Taufik \& Anis Tyas Kuncoro

menjadi guru kebatinan dan namanya diubah menjadi Ki Samin Surosentiko. Pengikutnya menyebut dengan Kyai (Ki) Samin Surosentika atau (Ki) Samin Surosentiko. Ki Samin Surosentiko masih mempunyai pertalian darah dengan Kyai Keti di Rajegwesi, Bojonegoro, dan masih mempunyai pertalian darah dengan Pangeran Kusumaningayu. Adapun Pangeran Kusumaningayu adalah nama lain dari Raden Mas Adipati Brotodiningrat yang memerintah Kabupaten Sumoroto (kini daerah kecil di Kabupaten Tulungagung) pada tahun 1802-1826.

Penyebutan sebagai masyarakat Samin, 'Wong Samin', merupakan penamaan dari orang-orang luar. Mereka sendiri menyebut diri mereka sendiri sebagai "Masyarakat Sikep", sehingga mereka lebih suka disebut dengan sebutan Masyarakat Sikep. Sementara Sikep memuat dua arti: Sikep (sikap) sebagai kata benda mempunyai makna Bakohing Kalbu (keteguhan hati atau kekuatan penentuan diri), sedangkan Sikep (memeluk) sebagai kata kerja memuat makna paling positif "persatuan hati". Menurut mereka semua manusia dimana-mana sama saja melaksanakan kehidupan pria menikahi wanita dan wanita menikahi pria. Akan tetapi, bahwa hanya masyarakat merekalah yang mengemukakannya dalam pengakuan formal dan menyebutnya sebagai identitas kemasyarakatannya.

Jika dilihat jumlah penduduk Desa Baturejo hingga bulan Desember Tahun 2016 tercatat 6135 jiwa dengan rincian jumlah penduduk laki-laki 3119 jiwa serta jumlah penduduk perempuan 3016 jiwa, ini menunjukkan bila Desa Baturejo termasuk desa yang padat penduduk. Meskipun termasuk desa padat penduduk, masyarakat Desa Baturejo masih saling menghargai satu sama lain, rasa solidaritas masih tinggi dan masih menerapkan sikap gotong-royong. Meskipun di Desa Baturejo terdapat masyarakat Suku Samin yang secara budaya dan tradisi hidup berbeda, kehidupan sosial masyarakat tetap berjalan dengan kondusif. Bahkan hampir sebagian besar masyarakat Suku Samin bekerja sebagai buruh tani menggarap

Ulul Albab: Jurnal Studi dan Penelitian Hukum Islam 
sawah milik penduduk Desa Baturejo, hal ini membuktikan bila antara masyarakat Suku Samin dan masyarakat desa terjalin hubungan dan komunikasi yang baik. Sikap gotong- royong ditunjukkan dengan adanya kerja bakti bersama membersihkan lingkungan, membangun jembatan desa, juga ketika ada warga yang sedang membangun rumah, mereka juga sambatan membantu. ${ }^{11}$

Sepintas tidak ada perbedaan antara masyarakat Suku Samin dengan penduduk biasa Desa Baturejo, dikarenakan masyarakat Suku Samin juga hidup selayaknya masyarakat zaman sekarang, masyarakat Suku Samin juga memiliki motor, televisi dan alat-alat modern lainnya. Namun aslinya kehidupan sosial masyarakat Suku Samin memiliki perbedaan dengan penduduk Desa Baturejo. Mereka mempunyai aturan tersendiri dalam menjalankan hidup bermasyarakat. Seperti halnya dalam bidang politik, meskipun mereka terkenal tidak patuh terhadap pemerintah, akan tetapi masyarakat Suku Samin tetap menyalurkan hak suaranya. Misalnya pada pemilihan umum legislatif dan pemilihan presiden tahun lalu masyarakat Suku Samin juga mengikuti, mereka mempunyai aturan dalam menentukan wakil rakyat, dimana pilihan mereka semuanya sama. Karena hal itu berdasarkan keputusan Kepala Suku Samin yang kemudian diikuti oleh masyarakat Suku Samin yang lain. ${ }^{12}$

\section{Budaya Perkawinan Masyarakat Suku Samin}

Tradisi perkawinan dalam masyarakat Suku Samin merupakan salah satu budaya masyarakat yang selalu dipegang teguh, pola perkawinan menjadi pola dalam kehidupan masyarakat. Perkawinan dalam masyarakat Suku Samin mempunyai beberapa tahapan yaitu: ${ }^{13}$

\footnotetext{
${ }^{11}$ Wawancara dengan BJ pada tanggal 17 Desember 2016 pukul 12.30.

${ }^{12}$ Wawancara dengan BS pada tanggal 17 Desember 2016 pukul 14.30.

${ }^{13}$ Wawancara dengan Kepala Suku Samin pada tanggal 24 Desember 2016 pukul 09.00 .
} 
$62 \mid$ Muhammad Taufik \& Anis Tyas Kuncoro

1. Nyumuk yaitu kedatangan keluarga calon kemanten putra ke calon kemanten putri untuk menanyakan keberadaan calon menantu, apakah sudah mempunyai calon suami atau masih gadis (legan).

2. Ngendek yaitu pernyataan calon besan dari keluarga kemanten putra kepada bapak-ibu calon kemanten putri, menindak lanjuti forum nyumuk. Pada prosesi ini biasanya ibu dari pihak calon kemanten putra memberikan cincin emas sebagai tanda telah diwatesi.

3. Nyuwito yaitu hari dilangsungkannya perkawinan didasari niat kemanten putra untuk meneruskan keturunan (wiji sejati, titine anak adam). Rentang waktu nyuwito tidak dibatasi, dan ditentukan oleh kedua kemanten jika sudah cocok. Kecocokan itu ditandai dengan keduanya telah melakukan hubungan intim.

4. Paseksen yaitu forum ungkapan dari kemanten putra di hadapan orang tua kemanten putri, keluarga, dan tamu undangan bila kemanten putra sudah merasa cinta dan berjanji setia terhadap pasangannya, ungkapan tersebut dilakukan setelah kemanten putra-putri melakukan hubungan intim.

Adat perkawinan masyarakat Samin yaitu "siji kanggo sak lawase becik kawitane becik saklawase" (satu untuk selamanya, baik awalnya baik untuk selamanya) menganut asas monogami. Selain itu masyarakat Samin melarang perkawinan dengan luar kelompoknya, jika orang luar akan kawin dengan orang Samin, harus tunduk dan mengikuti keyakinan serta adat kebiasaan masyarakat Samin. Sebaliknya, jika orang Samin ingin kawin dengan masyarakat di luar Samin, maka harus keluar dari kelompok Samin. ${ }^{14}$

${ }^{14}$ M. Zamzam Fauzanafi dkk, Inventarisasi dan Kajian Komunitas Adat Sedulur Sikep, (Yogyakarta: Balai Pelestarian Nilai Budaya (BPNB), 2012), 52.

Ulul Albab: Jurnal Studi dan Penelitian Hukum Islam 


\section{Pelaksanaan Tradisi Pasuwitan Sebagai Legalitas Perkawinan}

Pasuwitan adalah suatu tradisi yang terjadi di masyarakat Suku Samin, dimana merupakan salah satu tahapan perkawinan yang dijadikan sebagai legalitas nikah masyarakat Suku Samin. Prosesi pasuwitan berlangsung diawali dengan kedatangan pengantin putra yang diantar oleh kedua orang tuanya ke rumah pengantin putri. Selanjutnya pengantin putra memberikan pernyataan kepada orang tua pengantin putri, pak kerawuhan kulo wonten mriki bade tangklet kaleh panjenengan punopo lare wadon panjenengan taseh legan? Kemudian dijawab oleh orang tua pengantin putri, iyo le, iseh legan. Kemudian pengantin putra mengatakan, niku ajeng kulo rukun benjang nak mpun podo seneng nopo panjenengan lego? Dijawab orang tua pengantin putri, iyo le,,. Setelah proses tersebut pengantin putra hidup bersama keluarga pengantin putri atau sebaliknya dalam satu rumah untuk ngawulo kepada mertuanya, dengan membantu melaksanakan pekerjaan yang dilaksanakan mertuanya. Rentang waktu nyuwito tidak dibatasi waktu dan ditentukan oleh kedua kemanten jika sudah mengalami kecocokan. Kecocokan antara kemanten putra dan kemanten putri ditandai dengan keduanya telah melakukan hubungan intim. Setelah melakukan hubungan intim barulah pasangan kemanten dinyatakan sah sebagai suami isteri yang kemudian dilanjutkan ke tahapan paseksen, dengan mengundang tetangga sebagai saksi bahwa sepasang kemanten putra putri tersebut telah sah sebagai pasangan suami isteri. ${ }^{15}$

Pasuwitan dialami oleh pasangan SWK dan SRN selama dua bulan, setelah sebelumnya menjalani proses nyumuk dimana orang tua SWK datang ke rumah orang tua SRN untuk menanyakan apakah SRN masih legan atau tidak, serta proses ngendek, dimana orang tua SWK bermaksud melamar SRN.

${ }^{15}$ Wawancara dengan Kepala Suku Samin pada tanggal 26 Desember 2016 pukul 16.00 . 
$64 \mid$ Muhammad Taufik \& Anis Tyas Kuncoro

Setelah kedua proses tersebut, SWK hidup bersama dengan keluarga SRN dalam satu rumah. Ia ngawulo dengan membantu pekerjaan orang tua SRN yaitu menggarap sawah. Dalam proses tersebut SWK juga menjalani suatu proses pencocokan dengan SRN, hingga ia dan SRN merasa sudah cocok satu sama lain ditandai dengan ia dan SRN telah berhubungan intim. ${ }^{16}$

Hal tersebut juga dialami oleh pasangan PN dan TN selama delapan bulan, PN hidup bersama dengan keluarga TN untuk ngawulo kepada mertuanya yakni orang tua TN dengan membantu pekerjaannya. Selain itu ia juga menjalani proses pengenalan dan penyesuaian dengan $\mathrm{TN}$ untuk menuju proses kecocokan. Setelah menjalani proses penyesuaian dan pengenalan dengan $\mathrm{TN}$ dan merasa cocok dan telah berhubungan intim, maka ia dan TN dinyatakan sah sebagai suami isteri. ${ }^{17}$

Begitupun juga dialami oleh SSW dan MNK, kedua pasangan ini juga mengalami proses pasuwitan selama enam bulan. Setelah melalui tahapan-tahapan perkawinan yang sebelumnya, SSW diwajibkan terlebih dahulu melangsungkan proses pasuwitan sebelum dinyatakan sebagai suami isteri, dengan hidup bersama MNK dirumah orang tua MNK. SSW pun membantu pekerjaan mertuanya. Disela-sela ngawulo, SSW dan MNK juga menjalani penyesuaian hingga sudah merasa cocok dan berhubungan intim. ${ }^{18}$

Setelah melakukan hubungan intim pengantin putra memberikan ungkapan kepada orang tua pengantin putri dalam forum paseksen. Pernyataan pengantin putra, kulo bade ngandaaken syahadat kulo, bilih kulo sampun kukuh lan sampun demen janji sepisan kanggo selawase marang lare wadon panjenengan, inggeh meniko ngendiko kawulo panjenengan sekseni. Kemudian

${ }^{16}$ Wawancara dengan SWK pada tanggal 5 Januari 2017 pukul 16.30.

17 Wawancara dengan PN pada tanggal 5 Januari 2017 pukul 17.00.

18 Wawancara dengan SSW dan MNK pada tanggal 5 Januari 2017 pada pukul 17.30.

Ulul Albab: Jurnal Studi dan Penelitian Hukum Islam 
Pasuwitan Sebagai Legalitas .... 65

dijawab oleh orang tua pengantin putri dan keluarganya, iyo le...Kemudian dilanjutkan dengan doa oleh tokoh Samin untuk keselamatan kedua pengantin.

\section{Telaah Hukum Islam Terhadap Perkawinan Suku Samin}

Perkawinan merupakan salah satu peristiwa yang sangat penting dalam kehidupan masyarakat kita. Sebab perkawinan tidak hanya menyangkut wanita dan pria bakal mempelai, tetapi juga orang tua kedua belah pihak, saudara-saudaranya, bahkan keluarga-keluarga mereka masing-masing. Pernikahan adalah pintu gerbang yang sakral yang harus dimasuki oleh setiap insan untuk membentuk sebuah lembaga yang bernama keluarga. Perhatian Islam terhadap keluarga begitu besar, karena keluarga merupakan cikal bakal terbentuknya sebuah masyarakat yang lebih luas. Keluarga adalah pemberi warna dalam setiap masyarakat, baik tidaknya sebuah masyarakat tergantung pada masing-masing keluarga yang terdapat dalam masyarakat tersebut. ${ }^{19}$

Sedangkan mengenai dasar hukum perkawinan itu sendiri sudah dijelaskan dalam al-Qur'ān dan hadist. Dalam alQur'ān ayat yang menjelaskan perihal perkawinan antara lain sebagai berikut:

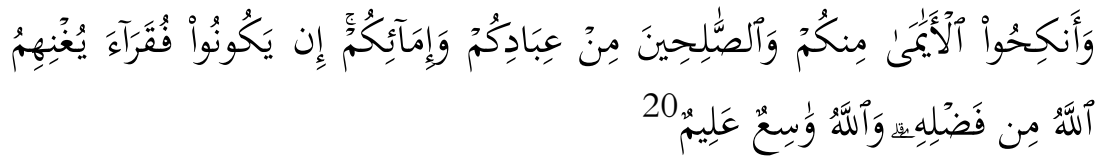

Artinya:

"dan kawinkanlah orang-orang yang sedirian diantara kamu, dan orang-orang yang layak (berkawin) dari hamba-hamba sahayamu yang lelaki dan hamba-hamba sahayamu yang perempuan. jika mereka

${ }^{19}$ MiftahFaridl, 150 Masalah Nikah Dan Keluarga, (Jakarta: GemaInsani Press, 2002), 1.

${ }^{20}$ Al-Nur: 32.

Vol. 1, No. 2, April 2018, 53-76 
$66 \mid$ Muhammad Taufik \& Anis Tyas Kuncoro

miskin Allah akan memampukan mereka dengan kurnia-Nya. dan Allah Maha Luas (pemberian-Nya) lagi Maha mengetahui."

Dari adanya sumber hukum diatas sudah jelas bahwa Rasulullah SAW memerintahkan kepada para pemuda yang sudah mampu dan sanggup baik secara materi maupun jasmani untuk segera menikah, karena dengan menikah akan dapat menjaga pandangan dari pandangan yang tidak halal, dan juga dapat menjaga kehormatan. Sedangkan bagi yang belum mampu Rasulullah SAW memerintahkan untuk berpuasa, karena dengan berpuasa dapat menahan syahwatnya.

Dalam perkawinan tentu tak lepas dari adanya tradisi disetiap desa masing-masing. Di masyarakat Suku Samin Desa Baturejo Kecamatan Sukolilo Kabupaten Pati ada tradisi perkawinan yaitu pasuwitan. Pasuwitan adalah suatu tradisi yang terjadi di masyarakat Suku Samin, dimana merupakan salah satu tahapan perkawinan yang dijadikan sebagai legalitas perkawinan masyarakat suku samin. Prosesi pasuwitan berlangsung dengan pengantin putra hidup bersama keluarga pengantin putri dalam satu rumah untuk ngawulo kepada orang tua pengantin dengan membantu melaksanakan pekerjaan yang dilaksanakan mertuanya. Rentang waktu nyuwito tidak dibatasi waktu dan ditentukan oleh kedua pengantin jika sudah mengalami kecocokan. Kecocokan itu terlihat dengan pengantin putra berhubungan intim dengan pengantin putri. Setelah melakukan hubungan intim barulah melakukan paseksen dengan mengundang tetangga sebagai saksi bahwa sepasang pengantin putra putri tersebut telah sah sebagai pasangan suami istri.

Pasuwitan merupakan sebuah tradisi yang dijadikan sebagai legalitas perkawinan oleh Suku Samin. Meskipun begitu, tradisi pasuwitan yang ada di masyarakat Suku Samin Desa Baturejo ini memiliki beberapa alasan diantaranya tradisi ini merupakan tradisi yang sudah turun temurun dan baik sehingga perkawinan Suku Samin dianjurkan dengan tradisi pasuwitan agar perkawinan mereka sah. adanya tradisi pasuwitan ini 
diharapkan kemanten putra dan kemanten putri bisa saling mengenal satu sama lain mulai dari sifat maupun tingkah lakunya karena keduanya telah hidup bersama dalam satu rumah dan dengan tradisi pasuwitan ini akan memperlihatkan kapatuhan dan ketaatan pengantin kepada mertuanya dengan adanya ngawulo.

Dari uraian diatas bisa dikatakan pasuwitan tidak sesuai dengan pengertian perkawinan yang terdapat dalam UndangUndang perkawinan No. 1 Tahun 1974 yang menyatakan bahwa, perkawinan adalah ikatan lahir bathin antara seorang pria dengan seorang wanita sebagai suami isteri, karena dalam pasuwitan pihak pria dan pihak wanita sedang menjalani proses pencocokan, dan belum ada ikatan lahir bathin, barulah ketika mereka sudah berhubungan intim ikatan suami-isteri melekat pada kedua pasangan.

Dalam tradisi pasuwitan bisa dikatakan juga tidak terdapat lagi kesakralan dan miitsaqon ghalidzan sebuah perkawinan, dimana ketika dalam proses tersebut tidak terdapat kecocokan antara kedua belah pihak, maka mereka bisa begitu saja meninggalkan pasangannya dan tidak melanjutkan tahapan perkawinan selanjutnya. Sehingga tujuan perkawinan untuk membentuk keluarga yang bahagia dan kekal tidak bisa dicapai.

Tradisi pasuwitan sebagai legalitas Perkawinan yang terjadi di masyarakat Suku Samin Desa Baturejo tidak sesuai dengan syarat-syarat diterimanya 'Urf sehingga tradisi pasuwitan ini tidak boleh dikerjakan oleh masyarakat.

Tradisi pasuwitan sebagai legalitas perkawinan masyarakat Suku Samin di Desa Baturejo menurut Islam yaitu:

a. Al 'urf al fasid adalah kebiasaan yang bertentangan dengan dalil-dalil syara' dan kaidah-kaidah dasar yang ada dalam syara'. Misalnya, kebiasaan yang berlaku di kalangan pedagang dalam menghalalkan riba, seperti peminjaman 
$68 \mid$ Muhammad Taufik \& Anis Tyas Kuncoro

uang antara sesama pedagang. ${ }^{21}$ Tradisi pasuwitan sebagai legalitas perkawinan masyarakat Suku Samin Desa Baturejo ini bertentangan dengan dalil-dalil syara' dan kaidahkaidah dasar yang ada dalam syara', menghalalkan yang haram dan mengharamkan yang halal.

b. Urf Fi'li yaitu kebiasaan yang berlaku dalam bentuk perbuatan. ${ }^{22}$ Tradisi pasuwitan yang ada di Suku Samin Desa Baturejo ini merupakan tradisi yang berbentuk perbuatan yakni menikahi pengantin putri tanpa adanya akad atau ijab qobul di depan para saksi dan berbuat intim dengan pengantin putri.

c. Urf Khusus yaitu 'urf yang hanya berlaku pada tempat, masa atau keadaan tertentu saja. ${ }^{23}$ Tradisi pasuwitan yang ada di masyarakat Suku Samin Desa Baturejo ini hanya berlaku di Suku Samin khususnya pada Desa Baturejo sendiri.

Berdasarkan penjelasan di atas penulis menyimpulkan bahwa tradisi pasuwitan sebagai legalitas perkawinan masyarakat Suku Samin di Desa Baturejo ini tidak boleh untuk dilakukan karena bertentangan dengan dalil-dalil syara' meskipun tradisi pasuwitan ini termasuk 'urf yang khusus dan 'urf amali tetapi 'urf ini termasuk 'urf yang fasid yang bertentangan dengan ketentuan syara' sehingga tidak boleh untuk dilakukan.

Sedangkan mengenai kehujjahan 'Urf itu sendiri yaitu para ulama sepakat bahwa 'urf shahih dapat dijadikan dasar hujjah selama tidak bertentangan dengan syara'. Ulama Malikiyah terkenal dengan pernyataan mereka bahwa amal

${ }^{21}$ Nasrun Haroen, Ushul Figh 1, (Jakarta, Wacana Ilmu, 1997), 141.

22 Amir Syarifudin, Hukum Perkawinan Islam di Indonesia, Antara Figh Munakahat dan Undang-Undang Perkawinan, Cet. 3, (Jakarta: Kencana Prenada Media Group, 2006), 391.

${ }^{23}$ Muin Umar, Ushul Figh 1, (Jakarta: Direktorat Jendral Pembinaan Agama Islam Departemen Agama RI, 1985), 152.

Ulul Albab: Jurnal Studi dan Penelitian Hukum Islam 
ulama Madinah dapat dijadikan hujjah, demikian pula ulama Hanafiyah menyatakan bahwa pendapat ulama Kufah dapat dijadikan dasar hujjah. Imam Syafi'I terkenal dengan qaul qadim dan qaul jadidnya. Ada suatu kejadian tetapi beliau menetapkan hukum yang berbeda pada waktu beliau masih berada di Makkah (qaul qadim) dengan setelah beliau berada di Mesir (qaul jadid). Hal ini menunjukkan bahwa ketiga madzhab itu berhujjah dengan 'urf. Tentu saja 'urf fasid tidak mereka jadikan sebagai dasar hujjah..$^{24}$ Sehingga berdasarkan apa yang telah dijelaskan dalam kehujjahan 'urf itu dapat ditarik kesimpulan bahwa 'urf yang fasid tidak dapat dijadikan sebagai hujjah karena bertentangan dengan dalil syara'. Tradisi pasuwitan megakibatkan tidak dicatatkannya perkawinan dihadapan petugas PPN dan juga sama saja membiarkan atau menghalalkan perbuatan zina karena sebelum adanya perkawinan yang sah keduanya telah melakukan hubungan intim (sebagai simbol kecocokan diantara keduanya). Padahal sudah jelas dalam firman Allah SWT:

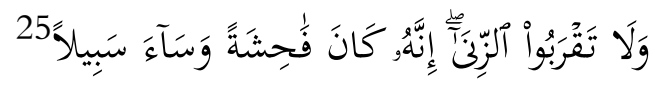

Artinya:

"Dan janganlah kamu mendekati zina; (zina) itu sungguh suatu perbuatan keji dan suatu jalan yang buruk".

Ayat tersebut sudah jelas bahwa Allah telah melarang untuk berbuat zina, bahkan perbuatan zina itu termasuk dosa besar dan Allah melaknatnya.

Argumentasi ini diperkuat dengan adanya prinsipprinsip perkawinan yang sudah jelas dalam undang-undang No 1 tahun 1974, bahwa perkawinan adalah sah apabila dilakukan menurut hukum masing-masing agamanya dan kepercayaanya itu, dan disamping itu tiap-tiap perkawinan harus dicatat

\footnotetext{
${ }^{24}$ Ibid., 152-153.

${ }^{25}$ Al-Isra': 32.
} 
$70 \mid$ Muhammad Taufik \& Anis Tyas Kuncoro

menurut peraturan perundang-undangan yang berlaku. ${ }^{26}$ Undang-undang tersebut sudah jelas bahwa tiap-tiap perkawinan itu harus dicatatkan, sedangkan jika dilihat dari apa yang terjadi di masyarakat Suku Samin Desa Baturejo ini sudah bertolak belakang, artinya kebiasaan yang ada di masyarakat Suku Samin Desa Baturejo tidak sesuai dengan peraturan yang ada. Jika dilihat dari hukum Islam maka kembali lagi dengan adanya syarat dan rukun perkawinan.

Syarat yaitu sesuatu yang mesti ada yang menentukan sah dan tidaknya suatu pekerjaan (ibadah), tetapi sesuatu itu tidak termasuk dalam rangkaian pekerjaan itu, seperti menutup aurat untuk shalat, atau menurut Islam calon pengantin lakilaki/ perempuan itu harus beragama Islam. Sedangkan rukun yaitu sesuatu yang mesti ada yang menentukan sah dan tidaknya suatu pekerjaan (ibadah), dan sesuatu itu termasuk dalam rangkaian pekerjaan itu, seperti membasuh muka untuk wudhu dan takbiratul ihram untuk shalat, atau adanya calon pengantin laki-laki/ perempuan dalam perkawinan. Sah yaitu sesuatu pekerjaan (ibadah) yang memenuhi rukun dan syarat. ${ }^{27}$ Rukun dan syarat menentukan suatu perbuatan hukum, terutama yang menyangkut dengan sah atau tidaknya perbuatan tersebut dari segi hukum.

Kaitannya dengan syarat dan rukun nikah, Imam alJaziri berpendapat bahwa apabila sebuah pernikahan tidak memenuhi syarat, maka nikahnya temasuk nikah fasid (akad nikahnya rusak). Sedangkan apabila tidak memenuhi rukunrukun nikah maka temasuk dalam nikah bathil (akad nikahnya tidak sah). ${ }^{28}$ Tradisi yang ada di Desa Baturejo ini sudah jelas

${ }^{26}$ Undang-undang RI No 1 Tahun 1974 tentang Perkawinan dan Kompilasi Hukum Islam, Cet. 3, (Bandung: Citra Umbara, 2013), 29-31.

${ }^{27}$ Abd. Rahman Ghazaly, Fiqh Munakahat, (Jakarta: Kencana, 2006), 45-46.

28 Abdurrahman al-Jaziry, al Figh 'ala Madzahib al Arba'ah, juz IV, (Surabaya: Dar al Taqwa, 2003),118.

Ulul Albab: Jurnal Studi dan Penelitian Hukum Islam 
tidak sesuai dengan syarat dan rukun Islam karena jika melihat dari syarat dan rukun perkawinan itu diantaranya:

a. Adanya calon suami dan isteri yang akan melakukan perkawinan.

b. Adanya wali dari pihak calon pengantin wanita.

c. Adanya dua orang saksi.

d. Sighat akad nikah, yaitu ijab qobul yang diucapkan oleh wali atau wakilnya dari pihak wanita, dan dijawab oleh calon pengantin laki-laki. ${ }^{29}$

Sedangkan syarat-syarat perkawinan merupakan dasar bagi sahnya perkawinan. Apabila syarat-syaratnya terpenuhi, maka perkawinan itu sah dan menimbulkan adanya segala hak dan kewajiban sebagai suami isteri.

Pada garis besarnya syarat-syarat sahnya perkawinan itu ada dua:

a. Calon mempelai perempuannya halal dikawini oleh laki-laki yang ingin menjadikannya isteri. Jadi, perempuannya itu bukan merupakan orang haram dinikahi, baik karena haram dinikahi untuk sementara maupun untuk selama-lamanya.

b. Akad nikahnya dihadiri para saksi. ${ }^{30}$

Jadi tradisi perkawinan yang ada di masyarakat Suku Samin Desa Baturejo jelas telah keluar dari syarat maupun rukun nikah yang ada sebagaimana yang telah dijelaskan di atas.

Dilihat dari segi akad pernikahan baru dianggap sah jika dilakukan dengan akad, yang mencakup ijab dan qabul antara wali wanita dengan laki-laki yang melamarnya, atau antara pihak yang menggantikannya seperti wakil atau wali, dan dianggap tidak sah hanya semata-mata berdasarkan suka sama suka tanpa adanya akad. ${ }^{31}$ Salah satu syarat akad yaitu Ijab dan qobul mesti menggunakan lafadz yang jelas dan terang. Menggunakan kata-kata nikah atau tazwij atau terjemah dari

\footnotetext{
${ }^{29}$ Abd.Rahman Ghazali, Fiqh Munakahat...., 49.

${ }^{30}$ Ibid., 49.

${ }^{31}$ M. Jawad Mughniyah, Figh Lima Madzhab, (Jakarta: Lentera, 1994), 13.
} 
$72 \mid$ Muhammad Taufik \& Anis Tyas Kuncoro

kata-kata nikah atau tazwij.32Ijab dan qobul tidak boleh menggunakan lafadz yang mengandung maksud membatasi perkawinan untuk masa tertentu.

Tradisi pasuwitan yang ada di masyarakat Suku Samin Desa Baturejo sudah jelas keluar dari syarat akad, dalam tradisi pasuwitan proses perkawinan tidak menggunakan ijab dan qabul secara jelas, mereka yang akan melakukan perkawinan hanya melaksanakan sebuah tradisi yaitu pihak pengantin putra datang kepihak pengantin putri untuk mengatakan bahwa dia menyukai anak perempuannya itu, setelah pihak pengantin putri menerimanya maka pengantin putra hidup bersama keluarga pengantin putri atau sebaliknya dalam satu rumah untuk ngawulo kepada orang tua pengantin dengan membantu melaksanakan pekerjaan yang dilaksanakan mertuanya. Kecocokan pengantin putra dan pengantin putri ditandai dengan keduanya telah melakukan hubungan intim. Setelah melakukan hubungan intim barulah pasangan pengantin dinyatakan sah sebagai suami istri yang kemudian dilanjutkan ketahapan paseksen, dengan mengundanng tetangga sebagai saksi bahwa sepasang pengantin putra putri tersebut telah sah sebagai pasangan suami isteri.

Bila dilihat dari ijab qabul salah satu syaratnya yaitu adanya pernyataan mengawinkan dari wali. ${ }^{33}$ Tradisi pasuwitan yang ada dimasyarakat Suku Samin Desa Baturejo bertentangan dengan pernyataan tersebut, perkawinan terjadi tanpa adanya pernyataan mengawinkan dari wali di dalam tradisi ini orang tua dari pengantin putri hanya mengizinkan pengantin putra untuk tinggal hidup di dalam rumahnya untuk ngawulo tanpa ada kata-kata mengawinkan. Perkawinan itu terjadi saat keduanya telah melakukan hubungan intim.

32 Ahmad Rofiq, Hukum Islam di Indonesia, (Jakarta: PT Sinar Grafika, 2010), 97.

${ }^{33}$ Ibid., 72.

Ulul Albab: Jurnal Studi dan Penelitian Hukum Islam 
Pasuwitan Sebagai Legalitas .... $\mid 73$

Sedangkan jika dilihat dari segi pasal undangundangnya, tradisi pasuwitan ini menimbulkan adanya legalitas dalam perkawinan. Padahal perkawinan yang sah adalah perkawinan yang dicatatkan di depan petugas PPN (Pegawai Pencatat Nikah) yang sesuai dengan pasal 2 ayat (2) UU No. 1 Tahun 1974 Tentang Perkawinan, sehingga perkawinan tersebut sudah dianggap legal atau sah dan akan mendapatkan buku kutipan akta nikah dari KUA sebagai akta autentik. Di masyarakat Suku Samin Desa Baturejo tradisi pasuwitan ini cenderung ke arah legalitas perkawinan. Warga Suku Samin Desa Baturejo tidak mencatatkan perkawinan karena mereka hanya mengikuti tradisi yaitu tradisi pasuwitan. Melihat dari pernyataan diatas perkawinan pasuwitan yang ada di masyarakat Suku Samin Desa Baturejo merupakan perkawinan ilegal karena perkawinan itu tidak dicatatkan di petugas PPN. Sehingga dari sisi ini perkawinan yang ada di masyarakat Suku Samin Desa Baturejo itu adalah perkawinan yang tidak sah karena perkawinan itu tidak dicatatkan di hadapan petugas PPN. Masyarakat di Suku Samin Desa Baturejo hanya meyakini perkawinan itu sah ketika keluarga atau ayah dari calon istrinya menerimanya dan telah melakukan hubungan intim, tidak perlu dicatatkan di depan petugas PPN.

Sehingga dapat ditarik kesimpulan bahwa tradisi pasuwitan yang ada di masyarakat Suku Samin Desa Baturejo ini jika dilihat dari rukun maupun syarat nikah atau menurut UU No 1 Tahun 1974 pernikahan yang terjadi dianggap tidak sah karena legalitas dalam perkawinan bukan ditentukan dari telah berhubungan intim, melainkan telah terpenuhinya syarat dan rukun nikah serta dicatatkan sesuai perundang-undangan yang berlaku.

\section{Kesimpulan}

Pernikahan merupakan sebuah fase yang harus dilalui oleh pasangan laki-laki dan perempuan ketika ingin menjalakan 
$74 \mid$ Muhammad Taufik \& Anis Tyas Kuncoro

kehidupan bersama dalam sebuah ikatan. sahnya sebuah perkawinan tergantung dari aturan dan syarat-syarat yang berlaku dalam Agama dan suku masing-masing, akan tetapi semua dijalankan dengan sebuah ritual yang bersifat sakral karena mengandung muatan tradisi dan keyakinan beragama antara hamba dan Tuhan-Nya.

Dalam menjalankan pernikahan masyarakat Suku Samin masih setia menjalankan tradisi pasuwitan, sebuah tradisi yang harus dilaksanakan ketika orang samin ingin melansungkan pernikahan sesuai adat dan aturan yang disepakati oleh masyarakat Suku Samin. Pasuwitan dilakukan dengan cara calon mempelai laki-laki hidup bersama di rumah calon mempelai perempuan atas dasar niat untuk mengabdi serta membantu calon mertua dalam menjalankan pekerjaan serta rutinitas sehari-hari seperti: bertani dan mencari makan hewan ternak.

Pasuwitan merupakan sebuah tradisi yang dijadikan legalitas perkawinan oleh masyarakat Suku Samin, dimana pasangan pengantin putra dan putri hidup dalam satu rumah untuk ngawulo hingga kedua pengantin mengalami kecocokan ditandai dengan berhubungan intim. Dalam menjalankan perkawinan, masyarakat Suku Samin enggan menjalankan peraturan perundang-undangan tentang perkawinan yang sudah berlaku seperti UU No 1 tahun 1974 dan Kompilasi Hukum Islam. Dari analisis penulis, menurut pandangan hukum Islam pasuwitan tidak boleh dilakukan sebab pasuwitan merupakan 'Urf Fasid, yang mana 'Urf atau tradisi tersebut bertentangan dengan dalil-dalil syar'i.

\section{Daftar Pustaka}

al-Jaziry, Abdurrahman. 2003. al Fiqh 'ala Madzahib al Arba'ah, Juz IV. Surabaya: Dar al Taqwa.

Ba'asyin, Anis Sholeh. 2014. Samin Mistisme Petani di Tengah Pergolakan. Semarang: Gigih Pustaka Mandiri. 
Pasuwitan Sebagai Legalitas .... $\mid 75$

Departemen Agama. 2012. Al-Qur'an dan Terjemahannya. Bandung: Diponegoro.

Faridl, Miftah. 2002. 150 Masalah Nikah Dan Keluarga. Jakarta:

Gema Insani Press.

Fauzanafi, M. Zamzam, et all. 2012. Inventarisasi dan Kajian

Komunitas Adat Sedulur Sikep. Yogyakarta: Balai

Pelestarian Nilai Budaya (BPNB).

Ghazaly, Abd. Rahman. 2006. Fiqh Munakahat. Jakarta: Kencana. Haroen, Nasrun. 1997. Ushul Figh 1. Jakarta: Wacana Ilmu.

Rofiq, Ahmad. 2010. Hukum Islam di Indonesia. Jakarta: PT. Sinar Grafika.

Saebani, Beni Ahmad. 2008. Perkawinan Dalam Hukum Islam dan Undang-Undang. Bandung: Pustaka Setia.

Syarifudin, Amir. 2006. Hukum Perkawinan Islam di Indonesia, Antara Figh Munakahat dan Undang-Undang Perkawinan,

Cet. 3. Jakarta: Kencana Prenada Media Group.

Umar, Muin. Ushul Figh 1. 1985. Jakarta: Direktorat Jendral Pembinaan Agama Islam Departemen Agama RI.

Undang-Undang Perkawinan No 1 Tahun 1974. 2012. Bandung: Citra Umbara.

Utomo, Stefanus Laksanto. 2013. Budaya Hukum Masyarakat Samin, Cet.1. Bandung: PT. Alumni.

Wasman \& Wardah Nuroniyyah. 2011. Hukum Perkawinan Islam Indonesia. Yogyakarta: Mitra Utama.

Witter, Turner Victor. 1996. The Ritual Process: Strukture and AntiStrukture. New York: Cornell University Press.

\section{Wawancara}

Wawancara dengan Kepala Suku Samin pada tanggal 23, 24, dan 26 Desember 2016 pukul 09.00

Wawancara dengan JMR pada tanggal 17 Desember 2016 pukul 12.30

Wawancara dengan SMH pada tanggal 17 Desember 2016 pukul 14.30

Wawancara dengan SWK pada tanggal 5 Januari 2017 pukul 16.30 
76 Muhammad Taufik \& Anis Tyas Kuncoro

Wawancara dengan PN pada tanggal 5 Januari 2017 pukul 17.00 Wawancara dengan SSW dan MNK pada tanggal 5 Januari 2017 pada pukul 17.30 